\title{
ANDRILL's Success During the 4th International Polar Year
}

\author{
by Fabio Florindo, David Harwood, Richard Levy, and SMS Project Science Team
}

doi:10.2204/iodp.sd.6.03.2008

\section{Introduction}

One of the scientific programs of the Fourth International Polar Year (Allison et al., 2007; www.ipy.org), the ANDRILL (ANtarctic geological DRILLing) Program demonstrated ability to recover high quality marine and glacimarine sedimentary drill cores from high latitude ice-covered areas. ANDRILL's inaugural 2006 and 2007 drilling seasons resulted in the two deepest drill holes on the Antarctic continental margin, recovering 2,400 meters of high-quality and nearly continuous sediment core. A chief scientific objective of this collaborative effort of scientists, engineers, technicians, students, educators, drillers, and support personnel from Germany, Italy, New Zealand, and the United States is the recovery of sedimentary archives from which past climatic and environmental changes in the southern high latitudes can be reconstructed. More than 120 individuals have been involved in each of the two drilling projects, eighty of whom worked in Antarctica during each austral summer season.

\section{Two Successful Antarctic Seasons}

Completed in early December 2007, the AND-2A drillcore of the Southern McMurdo Sound (SMS) Project (Figs. 1 and2) recovered $98 \%$ of the $1138.54 \mathrm{~m}$ of sedimentary rock penetrated, demonstrating that the ANDRILL drilling system (Figs. 1, 3, 4, and 5) is capable of consistently recovering high quality cores. The AND-2A drillcore is exceeded in depth only by ANDRILL's first drill hole AND-1B of the McMurdo Ice Shelf (MIS) Project (Fig. 2), which reached a total depth of $1284.87 \mathrm{~m}$ with similar success of high core recovery. Capable of operating in a range of environmental settings, the MIS Project drilled from an 84-m-thick ice shelf platform in 943 meters of water, and the SMS Project operated on the surface of $8.4 \mathrm{~m}$ of multi-year sea-ice over a 384-m water column. Alex Pyne, the Drilling Science Manager, merits recognition for the concept, design, and successful integration of elements of the ANDRILL drilling system.

Both of the ANDRILL projects reached their scientific targets. The MIS Project, led by Tim Naish (NZ) and Ross Powell (U.S.), recovered a record of a dynamic cryosphere of the last 13 million years of glacial and climatic variation of the West Antarctic Ice Sheet and Ross Sea region. The SMS Project (led by the authors of this report) completed drilling operations in late 2007 after recovering an expanded 600-m-thick section of the target interval that recorded a history of ice-proximal, shallow marine paleoenvironmental variation during the middle Miocene. This interval has long been held as a fundamental step in development of the Cenozoic cryosphere-interpretations of deep-sea oxygen isotope records suggest the middle Miocene encompassed a change from a period of warm climatic optima, approximately 17.5 $\mathrm{Ma}$ to $14.5 \mathrm{Ma}$, to the onset of major cooling between c. $14 \mathrm{Ma}$ to $13 \mathrm{Ma}$, and the formation of a quasi-permanent ice sheet on East Antarctica.

In addition to the 600-m-thick middle Miocene interval (800-223 mbsf), the AND-2A drill core also recovered an expanded lower Miocene section (1138.54 up to c. $800 \mathrm{mbsf}$ ) through an interval previously recovered during the Cape Roberts Project and an upper Pliocene to Recent interval (223 mbsf to $0.0 \mathrm{mbsf}$ ) that is thinner but correlative to parts of the Upper Neogene section recovered by the ANDRILL MIS Project in drill core AND-1B. Abundant volcanic clasts and tephra layers in the core, also provide the materials to document the 20-million-year evolution of the McMurdo Volcanic Province including several previously unknown explosive volcanic events.

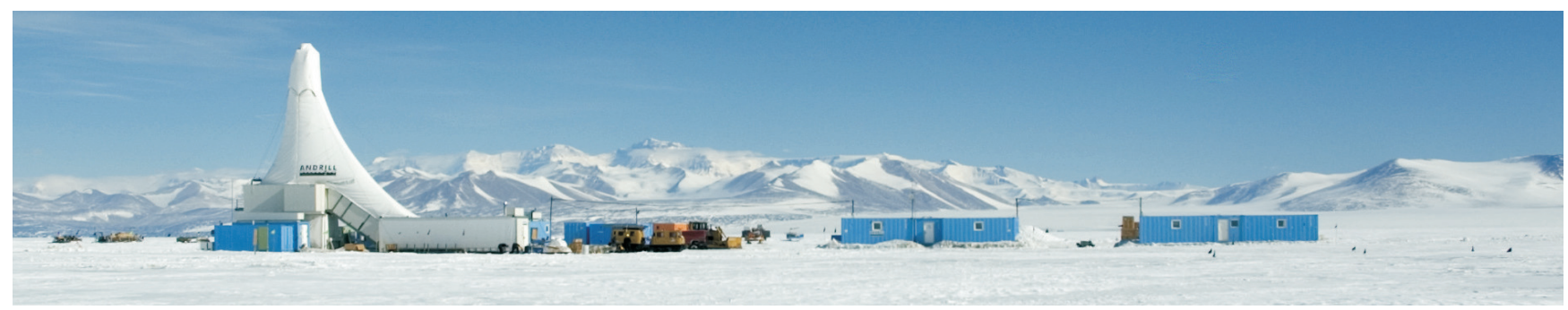

Figure 1. Panoramic image of the ANDRILL drilling rig and science laboratories in Southern McMurdo Sound during late 2007, operating from a 8.4-meter-thick sea-ice platform. Transantarctic Mountains are visible in the background. 


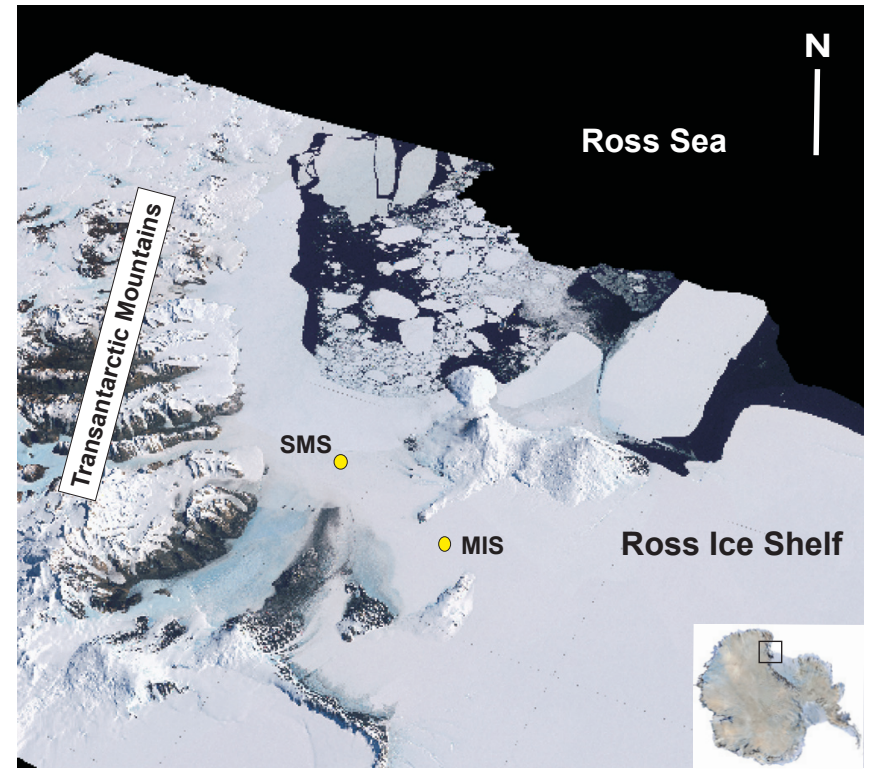

Satellite image of the McMurdo Sound region, including location of the Southern McMurdo Sound (SMS) and McMurdo Ice Shelf (MIS) drill sites.

Other results of the SMS Project include (1) a nearly continuous downhole logging operation, including deployment of a range of tools and a borehole televiewer, to match the excellent core physical (MSCL) and chemical (XRF scanning) properties data collected on-ice; (2) the first Antarctic in situ stress measurements from hydrofracture experiments conducted near the bottom of the borehole; (3) successful reconstruction and orientation of the core, using physical features, borehole tele-imaging, and a core orienting tool; (4) a robust chronostratigraphic framework, developed through integrated diatom biostratigraphy, magnetostratigraphy, and radiometric dating of volcanic materials, which now provides age control for the drill hole and the network of seismic lines in the western Ross Sea; (5) a vertical seismic profile study with three-component data; (6) the richest Cenozoic macropaleontological resource in East Antarctica, with more than fifty productive marine horizons; and (7) a record of terrestrial and marine temperature variations from a variety of climate proxies.

\section{Future Activities and Planning}

understanding of Antarctica's potential responses to future global climate change. With this in mind, the ANDRILL scientific and operations teams continue to plan for future scientific progress using the ANDRILL system through fieldbased site surveys, scientific planning, and technological developments. ANDRILL's capabilities are expanding to operate from an ice shelf platform several hundred meters thick and moving at a rate of more than two meters per day. The ANDRILL teams are also assessing the feasibility of reentering a drill hole, following relocation of the drilling rig and drill site science facilities. In the meantime, the science team members involved in the MIS and SMS projects are actively studying the drill cores and reporting initial results (Harwood et al., 2006, 2008; Naish, et al., 2007a, 2007b, 2008). These results are vital to SCAR's (Scientific Committee on Antarctic Research) ACE (Antarctic Climate Evolution) program (www.ace.scar.org), whose objectives are to integrate geological and paleoclimatic data into climate and ice sheet models to constrain estimates of Cenozoic ice volume variability, and terrestrial and marine paleotemperatures.

In support of the 4th IPY's focus on education and outreach objectives (http://www.ipy.org), ANDRILL is also engaging and training the next generation of Antarctic geoscientists and educators through exciting and collaborative international research and is taking polar science adventure into classrooms and homes through a stimulating and diverse education and outreach program (http://andrill.org/iceberg).

\section{Acknowledgements}

The ANDRILL project is a multinational collaboration between the Antarctic Programs of Germany, Italy, New Zealand, and the United States. Antarctica New Zealand is the project operator, and developed the drilling system in collaboration with Alex Pyne at Victoria University of Wellington and Webster Drilling and Exploration Ltd. Antarctica New Zealand supported the drilling team at Scott Base, and Raytheon Polar Services supported the Science team at McMurdo Station and the Crary Science and Engineering Center. Scientific support was provided by the ANDRILL Science Management Office, University of
Programs like ANDRILL can help constraining uncertainties about the future behavior of Antarctic ice sheets and resultant sea-level change. These stratigraphic records will be used to determine the behavior of ancient ice sheets and to better understand the factors driving past ice sheet, ice shelf, and seaice growth and decay. This knowledge will enhance our

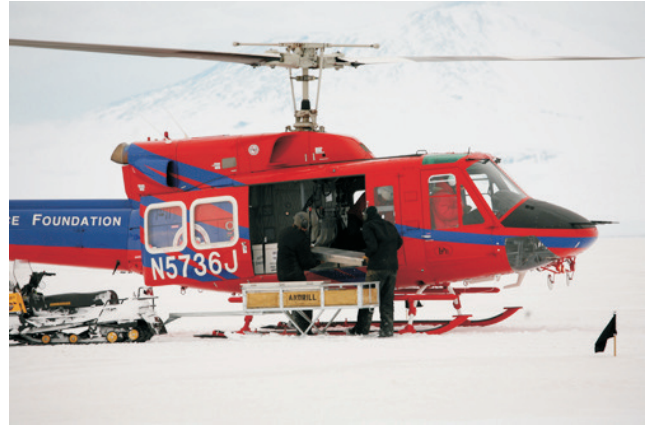

ANDRILL sediment cores were flown by helicopter daily from the drillsite to the Crary Science and Engineering Center at McMurdo Station. Photo by Lucia Simion.

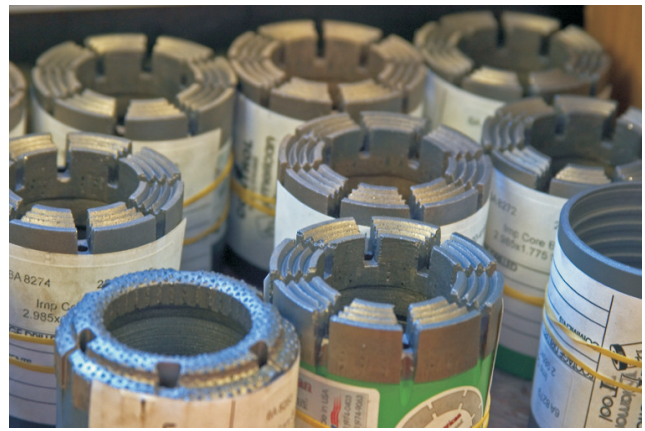

Diamond-impregnated drilling bits enable the ANDRILL drilling system to recover high-quality core, with up to $98 \%$ core recovery through glacial and glacimarine sediments. 


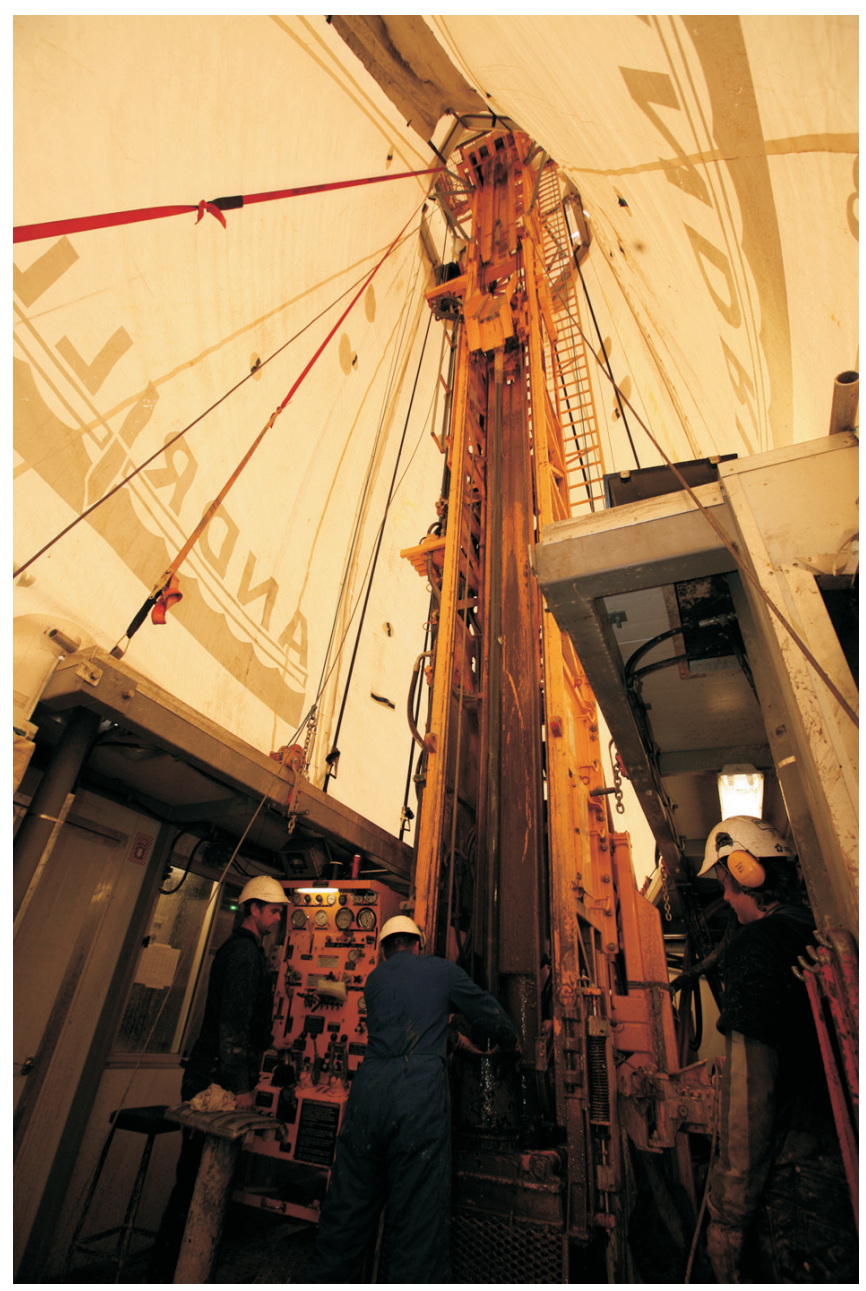

Figure 5. Drilling operations under the ANDRILL drill-rig canopy.

Nebraska-Lincoln. Scientific studies are jointly supported by the U.S. National Science Foundation, NZ Foundation for Research, the Italian Antarctic Research Program, the German Science Foundation, and the Alfred Wegener Institute. For more information, please visit the ANDRILL website at http://andrill.org.

\section{References}

Allison, I., Béland, M., Alverson, K., Bell, R., Carlson, D., Danell, K., Ellis-Evans, C., Fahrbach, E., Fanta, E., Fujii, Y., Glaser, G., Goldfarb, L., Hovelsrud, G., Huber, J., Kotlyakov, V., Krupnik, I., Lopez-Martinez, J., Mohr, T., Qin, D., Rachold, V., Rapley, C., Rogne, O., Sarukhanian, E., Summerhayes, C., and Xiao, C., 2007. The scope of science for the International Polar Year 2007-2008. WMO/TD-No.1364, Geneva (World Meteorological Organization), 1-79.

Harwood, D.M., Levy, R.H., Cowie, J., Florindo, F., Naish, T., Powell, R.D., and Pyne, A., 2006. Deep drilling with the ANDRILL program in Antarctica. Sci. Drill., 3:43-45.

Harwood, D.M., Florindo, F., Talarico, F., Levy, R.H., and SMS Science Team, 2008. Initial results of ANDRILL's Southern McMurdo Sound Project drill core AND-2A: early Miocene to Recent paleoclimate and geological history of the Victoria Land Basin, Antarctica. Geophys. Res. Abstr., 10:
EGU2008-A-12320.

Naish, T., Powell, R. D., Levy, R. H., Florindo, F., Harwood, D. M., Kuhn, G., Niessen, F., Talarico, F., and Wilson, G. S., 2007a. A record of Antarctic climate and ice sheet history recovered. Eos Trans. AGU, 88(50):557-558, doi:10.1029/ 2007EO500001.

Naish, T.R., Powell, R.D., and Levy, R.H., 2007b. Initial science results from AND-1B, ANDRILL McMurdo Ice Shelf Project, Antarctica. Terra Antartica, 14(3):111-328.

Naish, T.R., Powell, R.D., Barrett, P.J., Levy, R.H., Henry, S., Wilson, G.S., Krissek, L.A., Niessen, F., Pompilio, M., Ross, J., Scherer, R., Talarico, F., Pyne, A., and the ANDRILL-MIS Science Team, 2008. Late Neogene climate history of the Ross Embayment from the AND-1B drill core: culmination of three decades of Antarctic margin drilling. In Cooper, A. K. (Ed.), Antarctica: A Keystone in a Changing World. Proceedings of the 10th International Symposium on Antarctic Earth Sciences. Washington, DC (The National Academies Press), 71-82.

\section{Authors}

Fabio Florindo, Istituto Nazionale di Geofisica e Vulcanologia, Via di Vigna Murata, 605, 00143 Rome, Italy, e-mail: florindo@ingv.it

David Harwood and Richard Levy, ANDRILL Science Management Office, and Department of Geosciences, University of Nebraska-Lincoln, 126 Bessey Hall, Lincoln, Neb. 68588-0341, U.S.A., e-mail: dharwood1@unl.edu and rlevy2@unl.edu

*The names and affiliations of those SMS Project Science Team members engaged during the SMS Project's initial core characterization phase can be found at the Web site: http://andrill.org/projects/sms/team.html

\section{Related Web Links}

http://www.ipy.org

http://andrill.org

http://andrill.org/iceberg

http://www.ace.scar.org

\section{Photo Credits}

Fig. 1: Photo by Simon Nielsen

Fig. 2: Satellite image courtesy of Steve Fischbein

Fig. 4: Photo courtesy of ANDRILL

Figs. 3 and 5: Photo by Lucia Simion 